\title{
Different Cell Populations in Bovine Trabecular Meshwork: An Ultrastructural and Immunocytochemical Study
}

\author{
C. FLÜGEL, E. TAMM ANDE. LÜTJEN-DRECOLL \\ Department of Anatomy, University of Erlangen-Nürnberg, Krankenhausstraße 9, 8520 Erlangen, \\ Germany
}

(Received 11 June 1990 and accepted in revised form 18 October 1990)

\begin{abstract}
Bovine outflow tissue differs markedly from that of humans. Tissue culture studies on the cells of this region are often compared with those of primate trabecular meshwork cells. A thorough cytological and immunocytochemical characterization of the cells of the bovine chamber angle is lacking. We have therefore investigated the cells of the pectinate ligament, the reticular meshwork, the region adjacent to the aqueous plexus, the connective tissue region between reticular meshwork and ciliary muscle and the ciliary muscle itself, ultrastructurally and immunocytochemically with staining for the cytoskeletal proteins vimentin and desmin, for $\alpha$-smooth muscle-actin and rough endoplasmic reticulum (rER).

In the pectinate ligament and in the region adjacent to the aqueous plexus, the cells were found to have especially abundant rER and glycogen in their cytoplasm. Vimentin was abundant in the reticular meshwork as positive staining was seen both in frozen and paraffin sections. Alpha-smooth muscle-actin could be found in the region connecting ciliary muscle and reticular meshwork as well as in a small area adjacent to the posterior capillary loops of the aqueous plexus. Ultrastructurally, these cells resembled myotibroblasts. The ciliary muscle cells stained both for vimentin and for $\alpha$-smooth muscle actin.

Key words: anterior chamber angle; trabecular meshwork; ultrastructure; immunocytochemistry ; desmin; vimentin; $\alpha$-smooth muscle-actin; glycogen.
\end{abstract}

\section{Introduction}

The outflow tissue of the bovine eye is often used as a source of material for tissue culture studies. Fresh material is readily available and the cells grow and divide more easily than the corresponding primate cells. As in tissue culture studies with human and monkey meshwork cells, bovine cells derived from explants can produce various components of the extracellular matrix (Grierson et al., 1985; Kurosawa et al., 1987), they can phagocytose foreign particles and are able to migrate (Grierson et al., 1986; Day et al., 1986; Yue et al., 1987). One has, however, to take into consideration that the anterior chamber angle in bovine eyes, as distinct from that of the primate, consists of at least three different regions (Rohen, 1964):

1. A well developed pectinate ligament with large spaces of Fontana.

2. The trabecular meshwork which is more reticular than lamellar in structure.

3. A loosely arranged connective tissue between trabecular meshwork and ciliary muscle. The muscle itself is located far posteriorly and consists of small, loosely arranged longitudinal bundles.

In this study we have tried to find cytological markers for the cells of the different regions and have stained bovine chamber angle tissues with antibodies against rough endoplasmic reticulum (rER), vimentin, desmin and $\alpha$-smooth muscle-actin. In addition, the

Dedicated to Professor Ernst H. Bárány on occasion of his 80th birthday. ultrastructure of the different cell types, newly defined in this study, was analysed by electron microscopy.

\section{Materials and Methods}

Eleven freshly enucleated bovine eyes were obtained from a local abattoir. The eyes were cut equatorially, and from the anterior halves small 5-6-mm wide segments were prepared from each quadrant of the eye.

\section{Immunocytochemical Staining}

Frozen sections. For immunocytochemical staining, pieces from each quadrant were rapidly frozen in isopentane cooled with liquid nitrogen. Sections $(10 \mu \mathrm{m})$ were cut at a temperature of $-20^{\circ} \mathrm{C}$, mounted on chromealum gelatine coated glass slides, and fixed with acetone for $10 \mathrm{~min}$ at $-20^{\circ} \mathrm{C}$. After drying at room temperature, the sections were first incubated for $45 \mathrm{~min}$ in Blotto's solution (Duhamel and Johnson, 1985) to minimize non-specific staining, and then with the primary antibody for $90 \mathrm{~min}$. For demonstration of the intermediate filaments desmin and vimentin, monoclonal mouse anti-human desmin (Dakopatts, Hamburg, Germany), dilution of 1:50, and monoclonal mouse anti-swine vimentin (Dakopatts), dilution of $1: 5$, were applied to the slides. For the dilution, $0 \cdot 1 \mathrm{M}$ phosphate buffered saline (PBS), $\mathrm{pH}$ of $7 \cdot 2-7 \cdot 4$, was used. Demonstration of $\alpha$-smooth muscle-actin was performed with mouse monoclonal anti- $\alpha$-smooth muscle-actin (Sigma, St Louis, MO) 

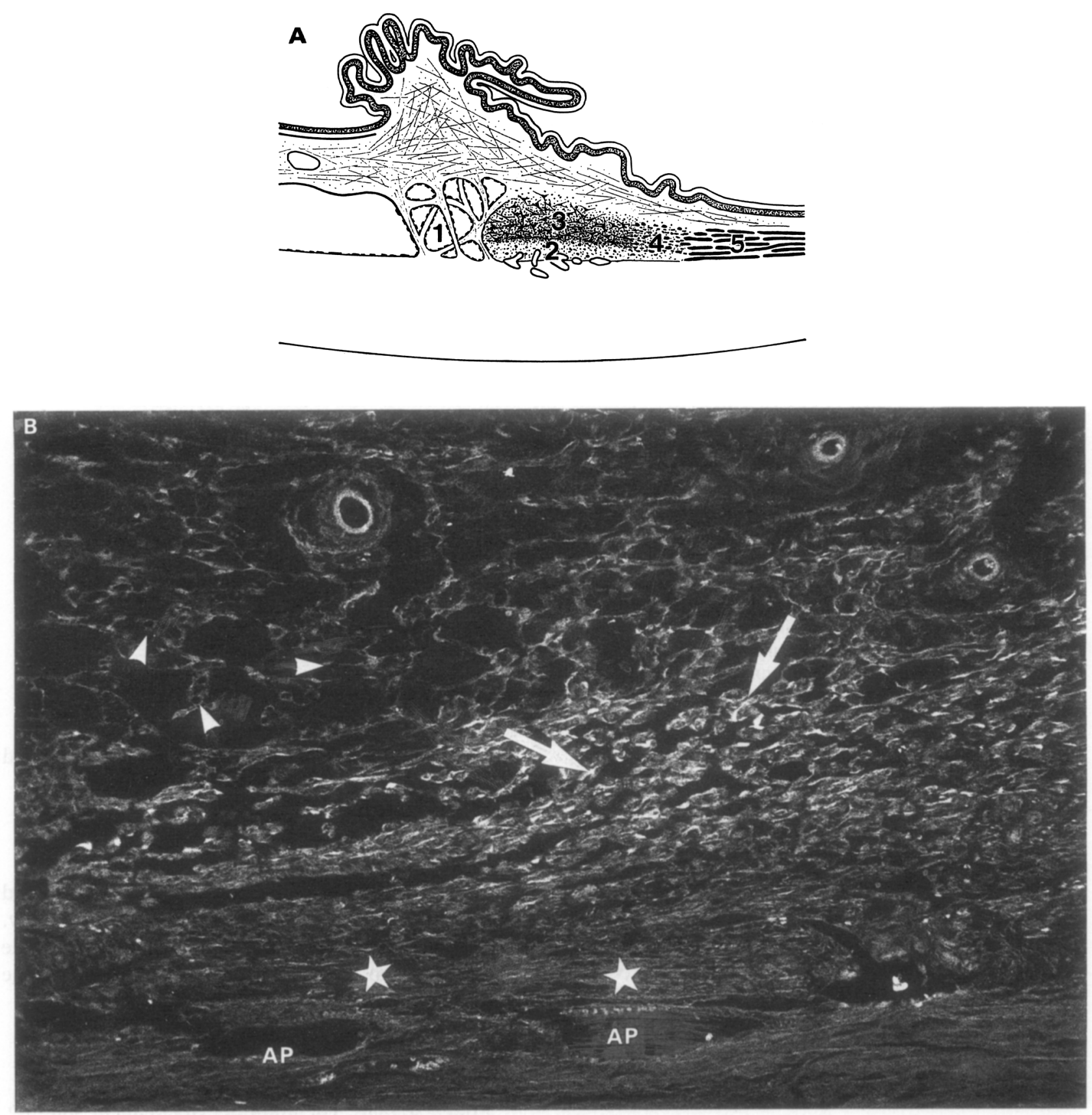

FIr. 1. A. Schematic drawing of a sagittal section through the bovine chamber angle of the superior or inferior quadrant: 1. pectinate ligament: 2 , region adjacent to the aqueous plexus; 3 . reticular meshwork: 4 . transitional region between reticular meshwork and ciliary muscle; and 5, ciliary muscle. In the nasal and temporal quadrants, the regions are in general the same, but regions 2, 3 and 4 are much shorter (see Fig. 2). B. Paraffin section through the bovine chamber angle of the inferior quadrant, stained with antibodies against vimentin. The section includes regions 2 and 3 , as well as parts of region 1 . In region 3, the cells are stained positively (arrows). whereas cells of region 1 (arrowheads) and 2 (asterisks) remain unstained. AP, Aqueous plexus. $\times 40$. C. Paraffin section through the same quadrant. stained with antibodies against $\alpha$-smooth muscle-actin. (The orientation differs from Fig. $1(\mathrm{~A})$, as cornea and reticular meshwork face the top and the ciliary muscle the bottom of the figure.) The ciliary muscle (CM), region 4 (arrows) and cells of the posterior parts of region 2 (arrowheads) are positively stained. The presence of $\alpha$-smooth muscle-actin-containing cells can also be seen in the media of arterial vessels, whereas scleral fibroblasts and the inner reticular meshwork cells (RM) remain unstained. AP. Aqueous plexus. $\times 25$.

(Skalli et al., 1986) diluted in PBS with $1 \%$ bovine serum albumin (1:150). Staining for rER was performed with monoclonal mouse-antihuman rER (Dakopatts) diluted 1:50 in PBS. Each incubation was performed in a moist chamber at room temperature. The sections were then washed three times with PBS, each for $10 \mathrm{~min}$, and incubated with either fluor- escein- or rhodamine-labeled rabbit-anti-mouse $\operatorname{IgG}$ diluted with PBS $(1: 20)$. After washing in PBS $\left(30 \mathrm{~min}\right.$ ) the slides were mounted in Entellan ${ }^{(\mathrm{k})}$ (Merck, Darmstadt, Germany) containing 2.5\% 1.4-diazobicyclo-octane (Dabco, Merck) (Johnson et al., 1982).

Paraffin sections. Demonstration of rER could only be performed on frozen material. For the immunocyto- 


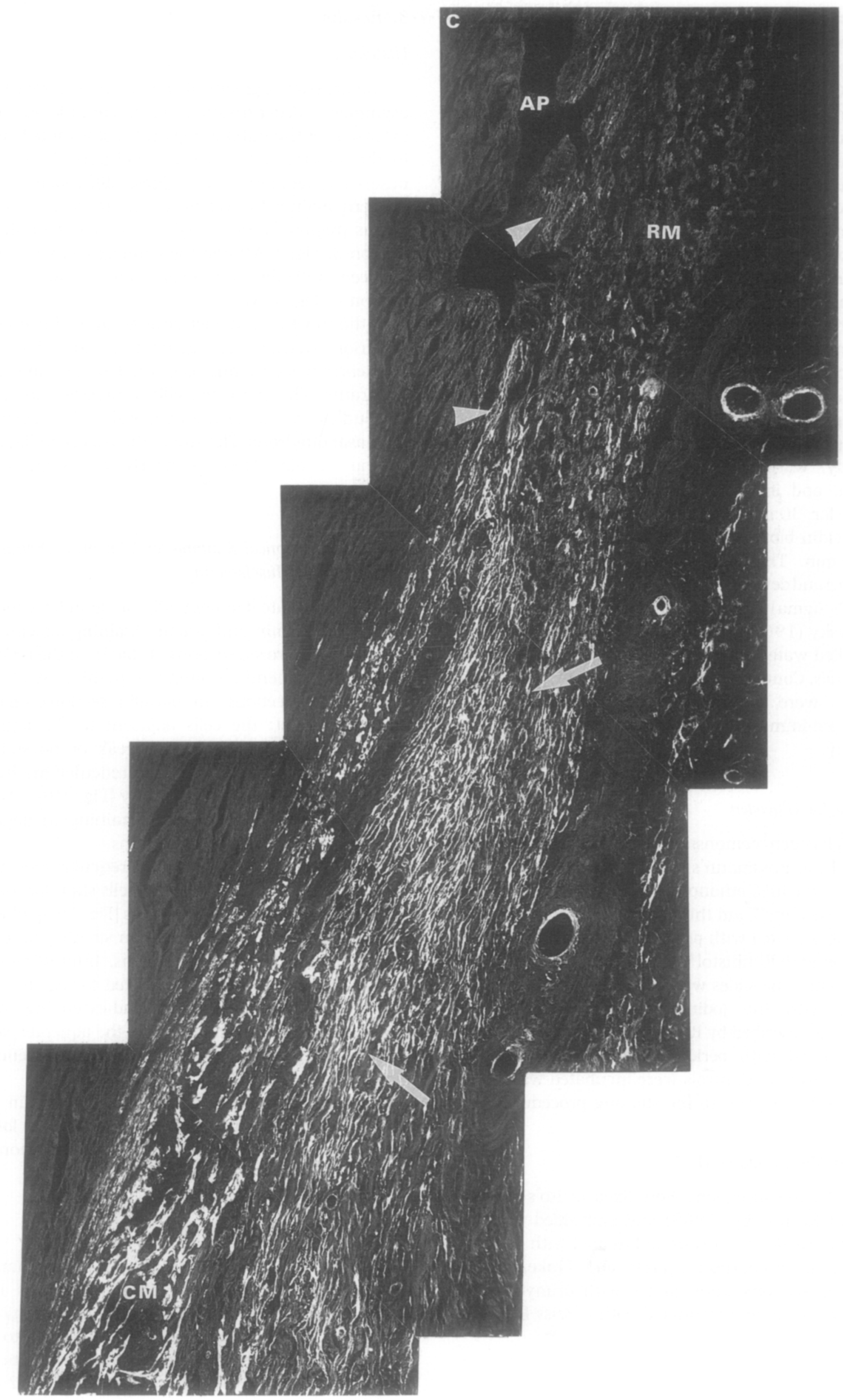

FIG. 1 (C). For legend see facing page. 
chemical demonstration of vimentin, desmin and $\alpha$ smooth muscle-actin, paraffin embedded material was also used. Pieces from each quadrant were fixed in paraformaldehyde-lysine-perjodate solution (PLP McLcan and Nakanc, 1974) for $4 \mathrm{hr}$ at $4^{\circ} \mathrm{C}$. After washing in PBS, the material was dehydrated and embedded in paraffin. Sagittal sections $(5 \mu \mathrm{m})$ as well as a series of slightly oblique sections through the chamber angle were cut and mounted on $0.1 \%$ poly-llysine-coated slides. To minimize non-specific staining, the deparaffinized sections were incubated for $20 \mathrm{~min}$ in normal rabbit serum (5\% in PBS). For indirect immunofluorescence staining, the sections were treated as described above: following incubation with the primary antibody the sections were incubated with the secondary antibody, washed, and embedded in Entellan with $2.5 \%$ Dabco $^{\circledR}$. For immunoperoxidasestaining the sections were pre-treated for $10 \mathrm{~min}$ with $\mathrm{H}_{2} \mathrm{O}_{2}$ ( $1 \%$ in PBS), incubated with the primary antibody, washed three times with PBS each for $10 \mathrm{~min}$, and incubated with sheep $\alpha$-mouse biotin $1: 200$ for $30 \mathrm{~min}$. After washing in PBS $(30 \mathrm{~min})$ streptavidin-biotin horseradish peroxidase was applied for $60 \mathrm{~min}$. 'The slides were then washed in PBS (30 $\mathrm{min}$ ) and developed with 3-amino-9-ethylcarbazole (3-AEC. Sigma) according to Graham, Lundholm and Karnovsky (1965). Finally, the sections were washed in distilled water and mounted with glycerin-gelatine.

Controls. Control experiments for frozen and paraffin sections were performed using either PBS or a mouse pre-immune serum substituted for the primary antibody.

\section{Staining for Glycogen}

For glycogen demonstration, two eyes were fixed overnight in Rossmann's solution (Rossmann, 1940), washed in $100 \%$ ethanol and embedded in paraffin. Sagittal sections $7 \mu \mathrm{m}$ thick were cut and mounted on glass slides coated with proteinglycerin. After deparaffinization with Rotihistol ${ }^{\circledR}$ (Roth, Karlsruhe, Germany) and ethanol, the slides were coated with celloidin and stained with the jodine-reaction after Langhans (1890), as described by Romeis (1973). Other sections were stained with periodic-acid-Shiff-(PAS)-solution or Best-Carmine. Controls were incubated with saliva for a few hours prior to the staining procedures.

\section{Electron Microscopy (EM)}

For EM, the specimens were fixed in Ito's solution (Ito and Karnovsky, 1968) and embedded in Epon. Semi-thin sections were cut and treated with Richardson's stain (Richardson, Jarett and Finke, 1960). Ultra-thin sections were stained with uranyl acctate and lead citrate and evaluated with a Zeiss EM 902.

\section{Results}

Histology

The anterior segment of the bovine eye reveals an asymmetric structure such that the anterior-posterior extension of the outflow region becomes much wider in the superior and inferior quadrants than in the nasal and temporal ones. These differences in size concern mainly the region adjacent to the aqueous plexus [region 2, Fig. 1(A)], the reticular meshwork [region 3. Fig. $1(A)]$ and the connective tissue region between reticular meshwork and ciliary muscle [region 4, Fig. 1(A)].

In the superior and inferior quadrants, the anteriorposterior extensions of regions 2, 3 and 4 [Fig. 1(A)] are nearly twice as long as in the temporal and nasal quadrants. Therefore, the ciliary muscle approaches the outflow region in the temporal and especially in the nasal quadrant. The size of the pectinate ligament [region 1, Fig. 1(A)] is nearly the same in all quadrants.

Immunocytochemical Staining for Vimentin, Desmin and Alpha-smooth Muscle-actin

In the pectinate ligament, all cells stain for vimentin but not for desmin and $\alpha$-actin. Staining for vimentin is seen only in frozen sections (Table I). In the reticular meshwork. vimentin staining is positive in all cells using frozen sections. In paraffin sections regional differences exist: the cells adjacent to the aqueous plexus (region 2) show either weak or no staining whereas in the main part of the reticular meshwork (region 3), the cells stain positively [Fig. 1(B)]. Alphasmooth muscle-actin and desmin staining are negative in both frozen and paraffin sections.

In the transition zone between reticular meshwork and ciliary muscle (region 4), all cells stain for $\alpha$-actin in both frozen and paraffin sections [Fig. 1(C)] whereas desmin is lacking. A faint vimentin staining occurs in frozen but not in paraffin sections. Interestingly, $\alpha$ actin positive cells are not restricted to region 4 , but some stained cells are always found extending anteriorly towards the posterior loops of the aqueous plexus [into region 2, Fig. $1(\mathrm{C})$ ] and towards the reticular meshwork.

The ciliary muscle stains intensely for desmin (Fig. 2) and $\alpha$-smooth muscle-actin. Vimentin is faintly positive in frozen but negative in paraftin sections.

\section{Immunocytochemical Staining for $r E R$ and Histochemical Staining for Glycogen}

Staining of $r E R$ is found in all cells of the chamber angle region (regions 1-4). The staining is most intense in the area of the pectinate ligament [region 1, Fig. 1(A)], in the region directly adjacent to the aqueous plexus (region 2) and in cells of the reticular meshwork (region 3) which are facing region 2 (Fig. 
TABLE I

Cytoplasmic components in the different regions of bovine anterior chamber

\begin{tabular}{|c|c|c|c|c|c|}
\hline \multirow[b]{2}{*}{ Chamber angle regions } & \multicolumn{5}{|c|}{ Intermediate filaments $(8-10 \mathrm{~nm}) /$ microfilaments $(6-8 \mathrm{~nm})$} \\
\hline & $\begin{array}{c}\text { Desmin } \\
\text { (frozen/paraffin } \\
\text { section) }\end{array}$ & $\begin{array}{c}\text { Vimentin } \\
\text { (frozen/paraffin } \\
\text { section) }\end{array}$ & $\begin{array}{l}\alpha \text {-smooth muscle-actin } \\
\text { (frozen/paraffin } \\
\text { section) }\end{array}$ & $\begin{array}{c}\text { rER } \\
\text { (frozen } \\
\text { section) }\end{array}$ & $\begin{array}{c}\text { Glycogen } \\
\text { (paraffin } \\
\text { section) }\end{array}$ \\
\hline 1. Pectinate ligament & $-1-$ & $(+) /-$ & $-1-$ & ++ & $\begin{array}{l}+ \\
\text { Single } \\
\text { cells }++\end{array}$ \\
\hline $\begin{array}{l}\text { 2. Region adjacent to } \\
\text { the aqueous plexus }\end{array}$ & $-1-$ & $(+) /-$ & $+1+$ & ++ & ++ \\
\hline 3. Reticular meshwork & $-1-$ & $+/+$ & $-1-$ & + & + \\
\hline $\begin{array}{l}\text { 4. Transitional region } \\
\text { in front of the } \\
\text { ciliary muscle }\end{array}$ & $-1-$ & $(+) /-$ & $+1+$ & + & + \\
\hline 5. Ciliary muscle & $+1+$ & $(+) /-$ & $+/+$ & $(+)$ & $1+1$ \\
\hline
\end{tabular}

\footnotetext{
- Absent staining.

$(+)$ Weak staining.

+ Visible staining.

++ Intensive staining.
}

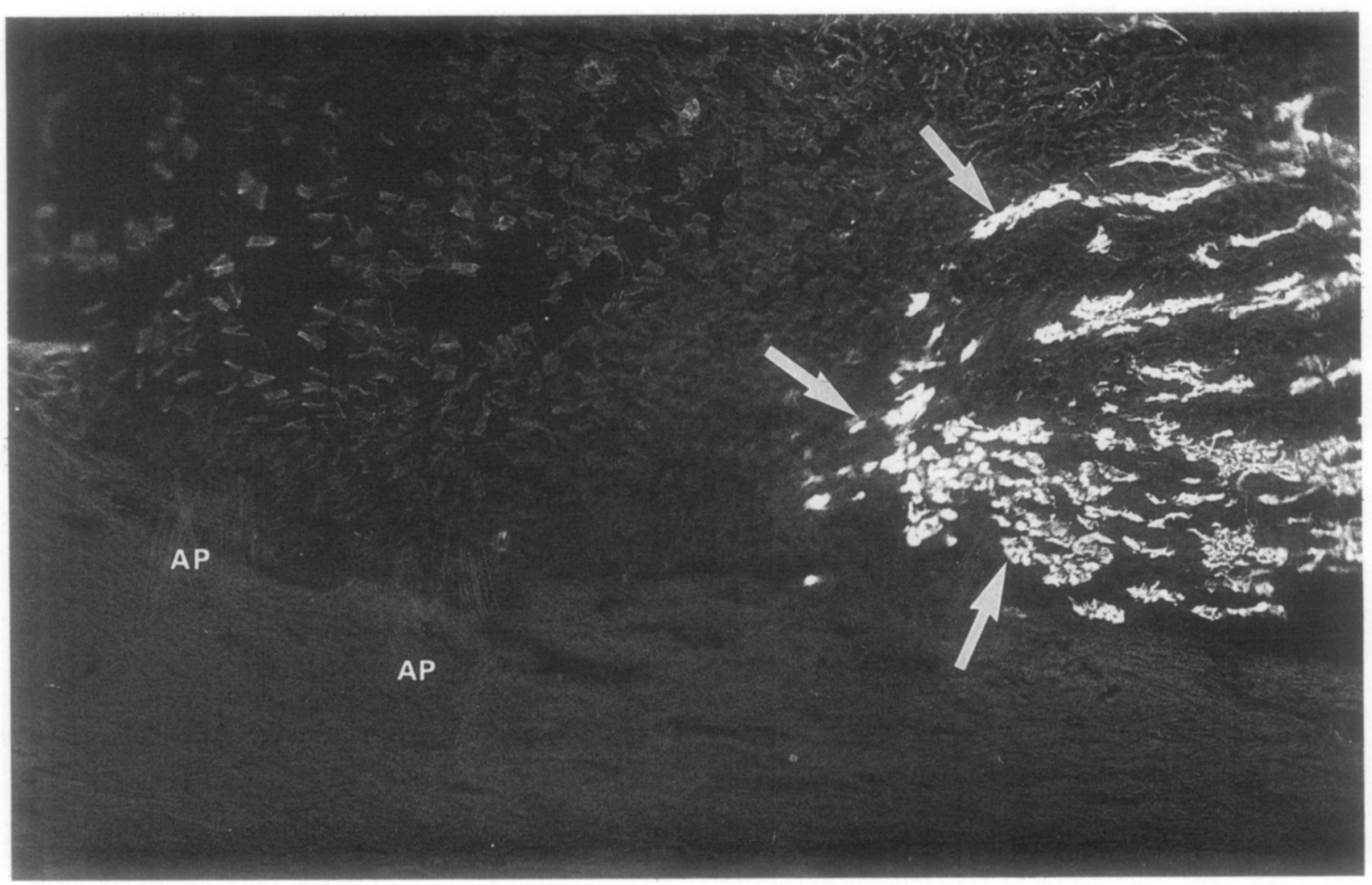

FIG. 2. Paraffin section through the nasal quadrant, stained with antibodies against desmin. Due to the small anteriorposterior extension of the chamber angle, all regions are included. Staining can only be seen in ciliary muscle cells (arrows). AP, Aqueous plexus. $\times 40$.

3). Little staining is seen in the ciliary muscle (Table I). Glycogen is also found in all cells of the meshwork (region 3). The staining is most intense in the cells adjacent to the aqueous plexus (region 2, Fig. 4) and in that part of the pectinate ligament which lies directly anterior to region 2 (Table I).

\section{Circumferential Differences}

Despite the fact that the extension of all four portions of the anterior chamber angle, especially of the regions 2, 3 and 4 [Fig. 1(A)], is much shorter nasally and temporally than in the superior and inferior quadrant, the staining characteristics of the 


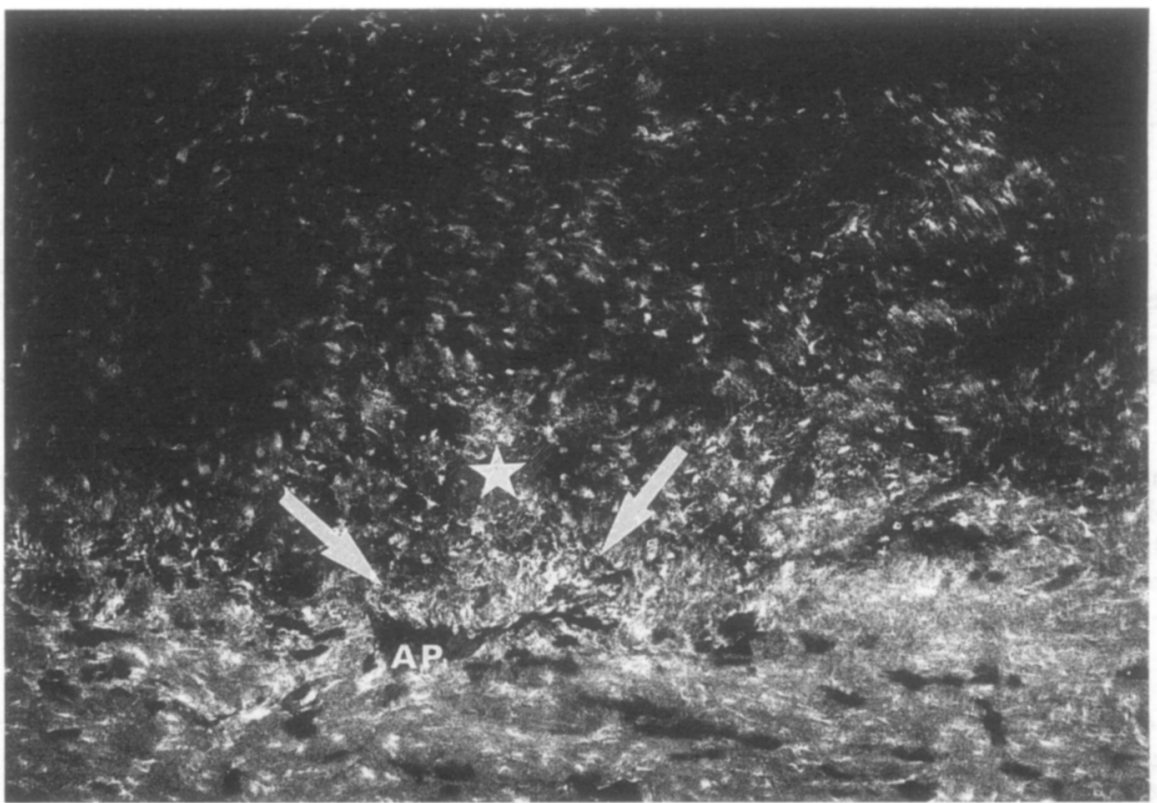

FIG. 3. Frozen unfixed section through the inferior quadrant, stained with antibodies against rough endoplasmic reticulum. The cells lying adjacent to the aqueous plexus (AP) (region 2, arrows) as well as the reticular meshwork cells (region 3, asterisk) facing region 2 are brightly stained. $\times 30$.

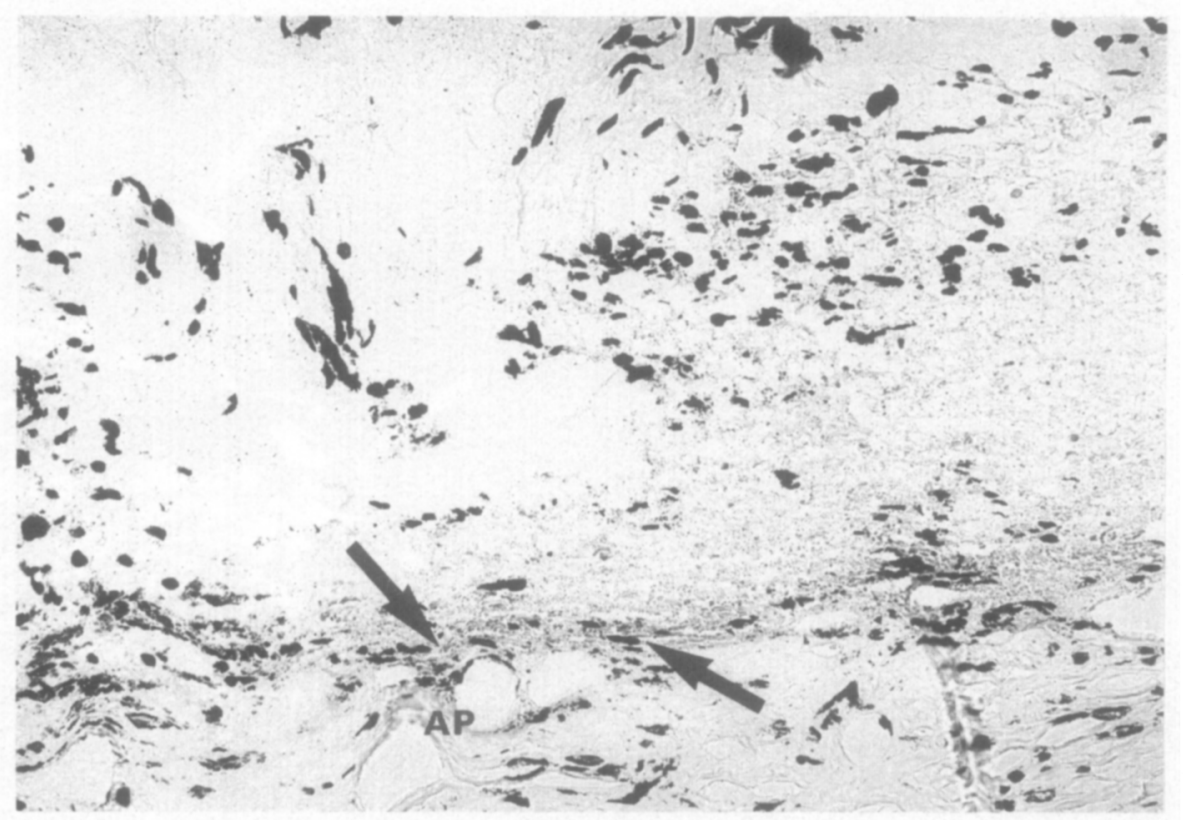

Fig. 4. Paraffin section through the inferior quadrant, stained for glycogen (jodine-reaction after Langhans/Romeis). The most intense staining is seen in region 2 (arrows) adjacent to the aqueous plexus (AP). $\times 30$.

Fig. 5. A, Electron micrograph of the transitional zone between reticular meshwork (region 3) and the region adjacent to the aqueous plexus (region 2). $\times 15400$. The cell at the bottom of the figure has large accumulations of glycogen granules (arrowheads) in the cytoplasm. Characteristically for region 2, 6-8 nm thick microfilaments can be seen forming small bundles in the cytoplasm adjacent to the cell membrane (arrow). The inset shows a higher magnification of these microfilaments $(\times 45000)$. The cell at the top of the figure shows the characteristics of a cell of region 3. Rough endoplasmic reticulum (rER) and glycogen (arrowheads) are present, however 6-8 $\mathrm{nm}$ thick microfilaments cannot be found. Between the cells, puncta adhaerentia and gap junctions (asterisk) can be seen. BM, Basement membrane. B, electron micrograph of a typical cell of region 4 , the transitional region between reticular meshwork and ciliary muscle $(\times 15400)$. The nucleus of the cell shows slight invaginations and the cytoplasm is nearly filled with microfilaments $(6-8 \mathrm{~nm}$, arrow). Gycogen and rough endoplasmic reticulum are only sparsely scattered between the densely packed microfilaments. The cell is scparated from dense connective tissue $(C)$ by an incomplete basal membrane (arrowhead). 

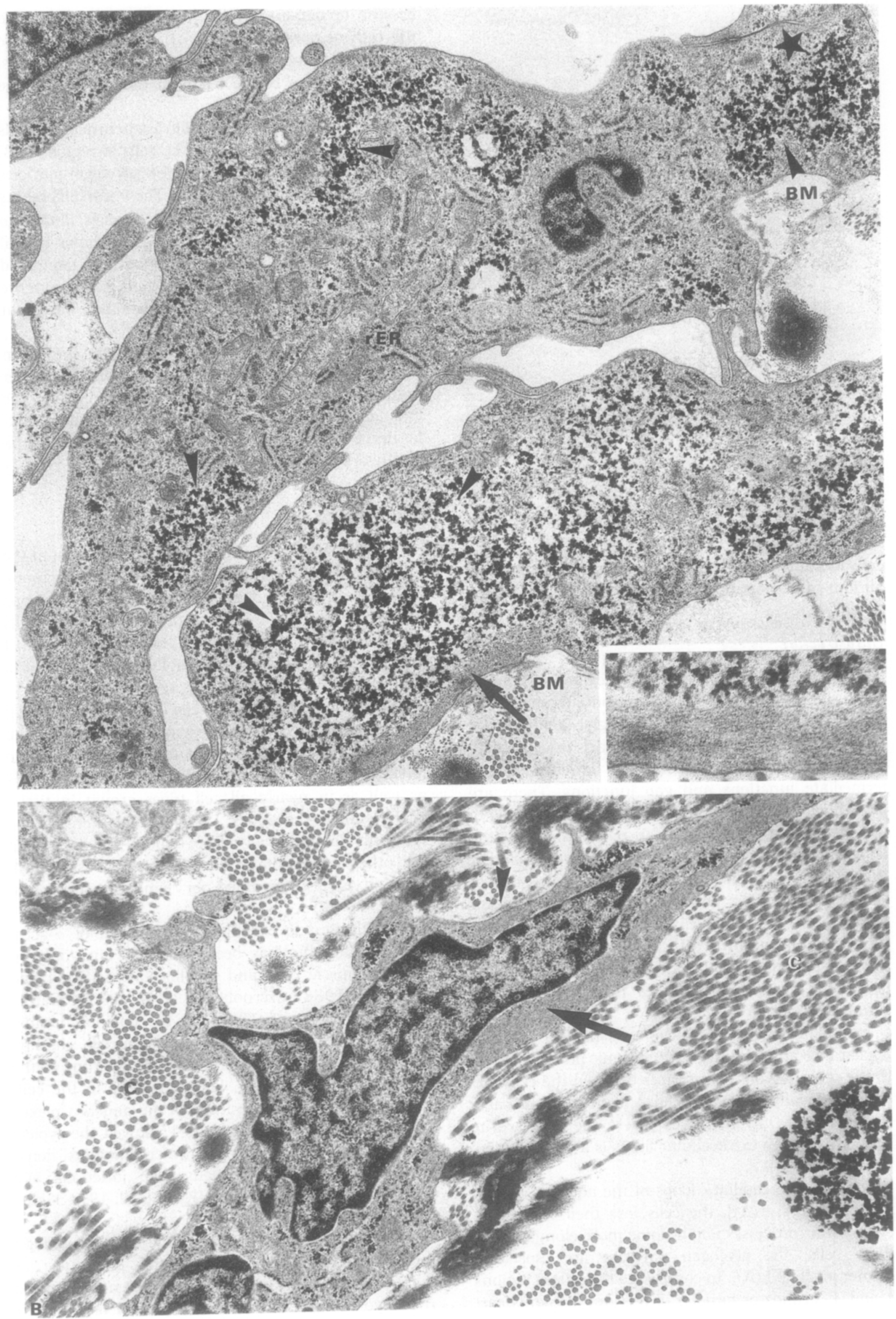

Fig. 5. For legend see facing page. 


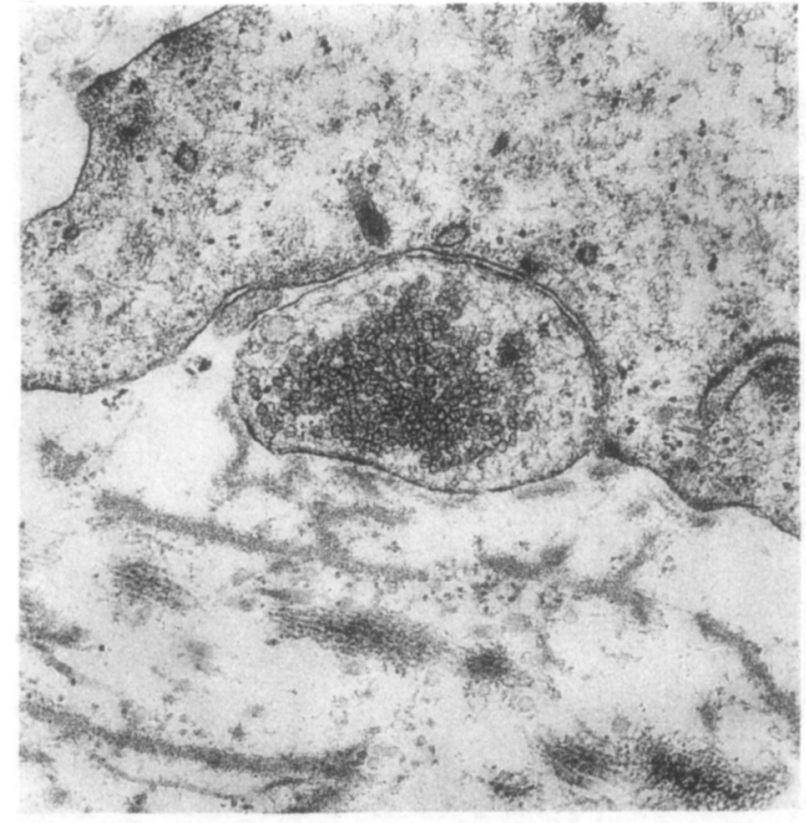

FiG. 6. Ultra-thin section of a nerve ending contacting a reticular meshwork cell. The nerve terminal contains empty vesicles and is closely apposed to the meshwork cell. $\times 40400$.

cells found within the defined regions are the same in all four quadrants of the chamber angle.

\section{Ultrastructure}

The ultrastructure of the cells in regions 1-3 shows some similarities. The cytoplasm contains numerous surfaces of rER, Golgi material and glycogen particles (Fig. 5). The cells are connected to each other by long cytoplasmic processes which form desmosomes, intermediate junctions and gap junctions. There are also, however, some differences between the cells of the different regions and their relationships to the adjacent connective tissue. In the pectinate ligament the cells cover connective tissue strands consisting of collagen and elastic fibres embedded in an electron lucent ground substance. The cells have an endothelial-like appearance with long cytoplasmic extensions overlapping each other. A nearly complete basement membrane separates the cells from the connective tissue core.

In region 3 [Fig. 1(A)] the cells have a star-like appearance and form more cytoplasmic processes than in the other regions. The spaces between the cells are either optically empty or tilled with collagen and elastic fibres. Only at places where the cells are in contact with the extracellular fibres is a basal lamina present [Fig. 5(A)].

Towards the capillary loops of the aqueous plexus [region 2, Fig. 1(A)], the cells lose their numerous cytoplasmic processes and become more elongated. In these cells, the glycogen particles are especially numerous [Fig. 5(A)]. In contrast to the cells of regions 1 and 3, strands or bundles of $6-8 \mathrm{~nm}$ filaments can be seen predominantly in the cytoplasm adjacent to the cell membranes [Fig. 5(A)]. Occasionally, dense bodies are found along these microflament strands, which are often connected with the cell membrane [Fig. 5(A)].

In region 4 [Fig. 1(A)], the ultrastructure of the cells differs markedly from that of the cells in regions 1-3. The cytoplasm contains only a few glycogen particles but is filled with microfilaments. These microfilaments are associated with numerous dense bodies. Similar to smooth muscle cells, the nucleus often shows typical invaginations [Fig. 5(B)]. On the other hand, compared to the ciliary muscle, the cells of region 4 contain more surfaces of rER and form only an incomplete basement membranc.

In the ciliary muscle cells themselves, the cytoplasm is filled with actin-filaments and contains few other organelles. The muscle is densely innervated by nerve endings containing empty vesicles. Occasionally, similar nerve terminals are also seen closely apposed to the meshwork cells of regions 1-4 (Fig. 6).

\section{Discussion}

Our results show that different cell types exist in the bovine chamber angle. The cells of the pectinate ligament and those directly adjacent to the aqueous plexus contain the largest amounts of rER. These cells are directly in the aqueous outflow pathway, and it could be that they are responsible for the renewal of the extracellular matrix of this region.

The reticular meshwork cells [region 3, Fig. 1(A)] are characterized immunocytochemically by the most intense staining for vimentin. The intermediate filament is found in the majority of mesenchymal cells as well as in nearly all cell types grown in tissue culture studies (Lazarides, 1982). In fact, there is some vimentin staining in all cells of regions $1-5$. Similar to the other intermediate filament types, a structural function is also assumed for vimentin (Lazarides, 1982).

Smooth muscle $\alpha$-actin is an isoform of $\alpha$-actin which until now has been found in vivo only in smooth muscle cells and myofibroblasts (Skalli and Gabbiani, 1988; Czernobilsky et al., 1989: Darby. Skalli and Gabbiani, 1990). In the bovine chamber angle, in addition to the ciliary muscle cells, staining for $\alpha$-actin is also found in the cells in front of the ciliary muscle [region 4, Fig. 1(A)] and in the cells adjacent to the capillary loops of the aqueous plexus (region 2). The cells in region 4 showed the typical morphology of myofibroblasts (microfilaments. dense bodies, rER, infolded nucleus, gap junctions and incomplete basal membrane) (Ryan et al. 1974; Skalli and Gabbiani, 1988).

The cells of region 2 have a different morphology and resemble rather a 'synthetic' phenotype of myolibroblasts having fewer microfilaments and more rER. Myofibroblasts, found in many other tissues such 
as alveolar septa and granulation tissue (for a review, see Skalli and Gabbiani. 1988), have been shown to have contractile properties (Gabbiani, Ryan and Majno, 1971). In fact, in a recent electrophysiological study, Coroneo et al. (1991) found a spindle-shaped cell type in monolayer cultures derived from bovine trabecular meshwork, that showed spontaneous or drug-induced depolarization of membrane potentials, as seen in smooth muscle cells.

The ciliary muscle cells can easily be distinguished from the $\alpha$-smooth muscle actin positive myofibroblasts of regions 2 and 4 . They are the only cells of the chamber angle cell which stain for desmin which is generally regarded as a typical intermediate filament found in the cytoskeleton of striated skclctal, cardiac and many visceral smooth muscle cells.

While the organization of the primate outflow system is well known and the importance of the filtering tissue is clear, the same is not true for the chamber angle of bovine eyes. Here, filtering takes place into the seemingly unsupported capillaries of the aqueous plexus. The problem is that if they really are unsupported, they would collapse when the intraocular pressure rises. We do not know whether innervation with non-adrenergic terminals and the rich supply of presumably contractile $\alpha$-smooth muscle-actin containing cells in this region suggests a supporting mechanism for these capillaries.

Glycogen is present predominantly in cells close to the outflow region, far distant from nutritive capillaries and presumably in a region with low oxygen tension. One may speculate that the glycogen becomes necessary when contractile activity of the $\alpha$-actin cells is needed.

The large size of the chamber angle, at least in the superior and inferior quadrants of the bovine eye makes it possible to take samples from the different locations. Such studies may prove whether functional differences of the cells in the different regions also exist in vitro.

\section{Acknowledgements}

We are grateful to Ute Maurer, Karin Göhler and Marco Gößwein for the expert technical assistance. This work was supported by a grant from the Deutsche Forschungsgemeinschaft (Dre 124/6-1).

\section{References}

Coroneo, M. T., Korbmacher, C., Flügel, C., Stiemer, B., Lütjen-Drecoll, E. and Wiederholt, M. (1991). Electrical and morphological evidence for heterogeneous populations of cultured bovine trabecular meshwork cells. Exp. Eye Res. 52, 375-88.

Czernobilsky, B., Shezen, E., Lifschitz-Mercer, B., Fogel, M., Luzon, A.. Jakob, N., Skalli, O. and Gabbiani, G. (1989). Alpha smooth muscle actin ( $\alpha$-SM actin) in normal human ovaries, in ovarial stromal hyperplasia and in ovarian neoplasms. Virchows Archiv B Cell Pathol. 57. $55-61$
Darby, I., Skalli, O. and Gabbiani, G. (1990). $\alpha$-Smooth muscle actin is transiently expressed by myofibroblasts during experimental wound healing. Lab. Invest. 63 , 21-9.

Day, J., Grierson, I., Unger, W. G. and Robins, E. (1986). Some effects of phagocytosis on bovine meshwork cells in culture. Exp. Eye Res. 43, 1077-87.

Duhamel, R. C. and Johnson, D. A. (1985). Use of nonfat dry milk to block nonspecific nuclear and membrane staining by avidin conjugates. J. Histochem. Cytochem. 33, $711-4$

Gabbiani, G., Ryan, G. B. and Majno. G. (1971). Presence of Inodified fibroblasts in granulation tissue and their possible role in wound contraction. Experientia 27. 549-50.

Graham, R. C., Lundholm, U. and Karnovsky, M. J. (1965). Cytochemical demonstration of peroxidase activity with 3-amino-9-ethylcarbazole. J. Histochem. Cytochem. 13, $150-2$.

Grierson, I., Day, J., Unger, W. G. and Ahmed, A. (1986). Phagocytosis of latex microspheres by bovine meshwork cells in culture. Graefe's Arch. Clin. Exp. Ophthalmol. 224, 536-44.

Grierson, I., Kissun, R., Ayad. S., Phylactos, A., Ahmed, S., Unger, W. G. and Day, J. E. (1985). The morphological features of bovine meshwork cells in vitro and their synthetic activities. Graefe's Arch. Clin. Exp. Ophthalmol. 223, 225-36.

Ito, S. and Karnovsky, M. J. (1968). Formaldehyde-glutaraldehyde fixatives containing trinitro compounds. J. Cell Biol. 39, 168a-9a.

Johnson, G. D., Davidson, R. S., McNamee, K. C., Russell, G., Goodwin, D. and Holborow, E. J. (1982). Fading of immunofluorescence during microscopy : a study of the phenomenon and its remedy. J. Immunol. Methods 55 , $231-42$.

Kurosawa, A., Elner, V. M., Yue, B. Y. J. T., Flvart, J. I. and Tso, M. O. M. (1987). Cultured trabecular meshwork cells: immunohistochemical and Lectin-binding characteristics. Exp. Eye Res. 44, 239-51.

Langhans, Th. (1890). Über Glycogen in pathologischen Neubildungen und den menschlichen Eihäuten. Virch. A. $120,28-67$.

Lazarides, E. (1982). Intermediate filaments: a chemically heterogeneous, developmentally regulated class of proteins. Ann. Rev. Biochem. 51, 219-50.

McLean, I. W. and Nakane, P. K. (1974). Periodate-lysineparaformaldehyde fixative: a new fixative for immunoelectron microscopy. I. Histochem. Cytochem. 22, $1077-$ 83.

Richardson, K. C., Jarett, L. and Finke, E. H. (1960). Embedding in epoxy resins for ultrathin sectioning in electron microscopy. Stain Technol. 35, 313-23.

Rohen. J. W. (1964). Das Auge und seine Hilfsorgane. In Handbuch der Mikroskopischen Anatomie des Menschen, vol. 3. pt 4. (Eds von Möllendorff, W. and Bargmann, W.). Pp. 189-237. Springer-Verlag: Berlin, New York.

Romeis, B. (1973). Mikroskopische Technik. (Ed. Böck, P.) Urban und Schwarzenberg: München, Wien, Baltimore

Rossmann. I. (1940). The deciduomal reaction in the rhesus monkey. Am. J. Anat. 66, 277-365.

Ryan, G. B., Cliff, W. J.. Gabbiani, G., Irle, C.. Montandon, D., Statkov, P. R. and Majno, G. (1974). Myofibroblasts in human granulation tissue. Hum. Pathol. 5, $55-67$.

Skalli, O. and Gabbiani, G. (1988). The biology of the myofibroblast relationship to wound contraction and fibrocontractive diseases. In The Molecular and Cellular Biology of Wound Repair. In (Eds Clark, R. A. F. and Henson, P. M.) Pp. 373-402. Plenum Publishing Corporation: New York. 
Skalli, O., Ropraz, P., Trzeciak, A., Benzonana, G., Gillessen, D. and Cabbiani, G. (1986). A monoclonal antibody against $\alpha$-smooth muscle actin : a new probe for smooth muscle differentiation. I. Cell Biol. 103, 2787-96.
Yue, B. Y. J. T., Elner, V. M., Elner, S. G. and Davis, H. K. (1987). Lysosomal enzyme activities in cultured trabecular meshwork cells. Exp. Eye Res. 44, 891-97. 